\title{
Okul Yöneticilerini Etik İkileme İten Baskı ve Güç Kaynaklarının Okul Kademelerine Göre İncelenmesi
}

\author{
SAFFET KARAYAMAN* \\ saffetkarayaman@gmail.com \\ ORCID ID: 0000-0001-5624-4678
}

Öz: Bu çalışmada okul yöneticilerini etik ikileme iten güç kaynaklarını, baskı grupların, okul düzeylerine göre belirlemek amaçlanmıştır. Okul müdürleri ve müdür yardımcıları, okul yöneticisi olarak ele alınmıştır. Okullar; İlkokul, Ortaokul ve Lise kademeleri olarak ele alınmıştır. Araştırma nitel bir durum çalışması türünde olup, çoklu durum deseni kullanılmıştır. Çalışmaya kolay ulaşılabilir örnekleme yöntemi ile seçilen elli okul yöneticisi katılmıştır. Katılımcıların kimliklerinin anlaşılmamasına özellikle dikkat edilmiştir. Veriler, standartlaştırılmış açık uçlu sorularla toplanmış ve kategorisel içerik analizi ile incelenmiştir. Toplanan veriler ışı̆̆ında, okul yöneticilerinin karşılaştıkları etik ikilemlere neden olan güç ve baskı kaynakları yedi grupta toplanmıştır. Tüm kurumlarda en yoğun üç etik ikilem kaynağı olarak; "sendikalar, dernek ve vakıfların beklentileri; üst makamların popülist uygulamalarl; üstlerin yetenek ve becerileri” olarak sıralanmıştır. Okul yöneticilerinin karşılaştığı etik ikilemlere neden olan güç kaynaklarının okul türlerine göre farklılaştığı bulunmuş ve farklılaşmanın nedenleri tartışılmıştır. Son bölümde, okul yöneticilerinin etik ihlallerden nasıl uzak durabileceklerine ilișkin önerilerde bulunulmuştur. ${ }^{1}$

Anahtar kelimeler: Okul yöneticileri, Etik ikilem kaynakları, Baskı, Okul kademesi

\section{Giriş̧}

İnsanlığın var olmasıyla başlayan yönetim olgusu, sanatların en eskisi, bilimlerin en yenisi olarak kabul edilmektedir. İnsan varsa yönetim de var demektir. Yönetim kavramı, organizasyon faaliyetini de içerir. İnsanlık tarihi boyunca yönetim ve organizasyon süreçlerini inceleyen bilim insanları, bu süreçleri çeşitli gelişim evrelerine ayırmışlardır. Klasik öncesi, klasik, neoklasik, modern ve post modern yaklaşımlar olarak isimlendirilen bu evreler her geçen gün yönetim ve organizasyon kavramının gelişim içerisinde olduğunu ifade eder. ${ }^{2}$ Ancak, tarihin herhangi bir dönemindeki bir yönetici, uyguladığı yönetim tarzını kendisi isimlendirmemiştir. Burada bilim insanlarının, kategorileștirmeleri ve adlandırmaları söz konusudur.

\footnotetext{
${ }^{*}$ Dr., Milli Eğitim Bakanlı̆̆ı.

${ }^{1}$ Bu çalışmadaki veriler 2020 yılı öncesinde derlenmiştir. Bu nedenle TR Dizin kriterleri arasında yer alan etik kurul onayı koşulundan muaf olduğu değerlendirilmektedir.

2 Tamer Koçel, İşletme Yöneticiliği, Ankara, Beta Yayınevi, 2013.
} 
Gayet tabiidir ki, her çağın veya uygarlığın kendine göre felsefesi, teknolojik düzeyi ve yaşam tarzı vardır. Uygarlığının gelişim süreci içinde, yönetimin önemi artmış, bilimsel yazında da her geçen gün daha fazla araştırılan bir konu haline gelmiştir. Günümüzde yönetim bilimi, uzmanlık ve mesleğe göre gruplara ayrılarak incelenir olmuştur.

Yönetim biliminin önemli bir alt dalı da eğitim yönetimi olup, alanının çekirdeğinde okul yöneticisi vardır. Okulun amaçlarını yerine getirmede, toplumsal gelişime ve medeniyete sunacağı katkıda okul yöneticisinin oynayacağ rolün önemi tartışılmaz. Modern toplum yapısının gereği eğitim organizasyonlarında sorunlar daha yoğun ve karmaşık bir hal almış durumdadır. Okul yöneticilerinin, bugün eskiye göre daha çok şey bilmeleri, farklı becerilere sahip olmaları, ${ }^{3}$ problemleri doğru tespit edip, doğru karar verebilen üstün bireyler olmaları ${ }^{4}$ beklenmektedir. Bu nedenle okul yöneticilerinin de değişerek, sürekli farklılaşan bu dinamik yapıya uyum sağlamaları zorunlu olmaktadır. Okul yöneticisi, devlet örgütünün, topluma dokunduğu en uç hücresidir ve toplum onu çok fazla şeyin sorumlusu olarak alg1lamaktadır. Bu durum; okul yöneticilerinin toplumdaki pek çok güç dinamikleri ile bir ilişki içerisinde olmasını kaçınılmaz kılmaktadır. Bir okul yöneticisi, mahallesindeki; muhtarın, derneklerin, dini önderlerin, yerel siyasilerin, halkın taleplerini iletildiği kişidir. Özellikle az gelişmiş ve gelişmekte olan toplumlarda muhatap doğrudan müdürün kendisidir. Mevzuatın ne dediği çok önem arz etmediği söylenebilir. Sınırsız beklenti sahibi insanoğlunun bir talebinin karşılanabilirliği her ne kadar yasayla çizilmiş olsa da; nihayetinde talebin karşılanmaması durumunda okul yöneticisi sorumlu tutulmaktadır. Bu nedenle, okul yöneticisi karşılaştığı talebi yerine getirdiği ölçüde bahsedilen otoritelerce kabul görecek ya da istenmeyecektir. Diğer bir ifadeyle, yerine getiremediği her talebin sorumlusu müdür olmakta ve bu durum ne kadar artarsa müdürün görevinde kalması da o kadar zorlaşmaktadır. Gücü elinde bulunduran odak, halktaki teveccühünü arttırmak için, bölgesindeki okul yöneticisinin, kendi taleplerini yerine getiren biri olmasını isteyebilir.

Yönetim işinin özünü karar vermek oluşturur. Koçel, yönetim sürecinde en temel işlevin karar vermek olduğunu ifade ederek, karar veremeyen yöneticinin aslında işini yapmadığını belirtmektedir. ${ }^{5}$ Yöneticinin motivasyon seviyesi de onun karar verme stilini etkileyebilmektedir. Düşük motivasyon düzeyine sahip olan ve risk almaktan kaçınan bireyler daha uzun süre düşünerek karar vermek istemektedirler. Motivasyonu yüksek ve risk alabilen bireyler ise daha hızlı kararlar alabilmektedirler. ${ }^{6}$ Okul yöneticilerinin bu görevlerini yerine getirirken var olan yasa ve politikalar kadar mesleki etik ilkelere de uygun davranmaları beklenir. ${ }^{7}$ Tüm bunlarla birlikte, yönetici karar verirken, bir takım etkiler altındadır; Kendisinden birtakım beklentiler içerisinde olan iç ve dış paydaşlar bulunmaktadır. Karardan etkilenenlerin çeşitli güç otoriteleri ile ilişki içerisinde bulundukları göz ardı edilemez. Bu

\footnotetext{
${ }^{3}$ Gökhan Baş, "Yüzyılda Eğitim Yöneticisinin Rolündeki Değișim ve Dönüşüm”, Eğitişim Dergisi, 30 (2011).

${ }^{4}$ Selahattin Turan ve Gamze Yalçın, "Okul Yöneticilerinin Yaptığı ve Yapmak İstediği İşler ile İş Doyumları Arasındaki İlişkinin İncelenmesi”, Kalem Eğitim ve İnsan Bilimleri Dergisi, 5/2 (2015), s.18.

${ }^{5}$ Koçel, İşletme Yöneticiliği i, s.110.

${ }^{6}$ Feriha Balkış Baymur, Genel Psikoloji, İstanbul: İnkılâp Kitabevi, 2014, s.47.

${ }^{7}$ Haydar Taymaz, Okul Yönetimi, Ankara: Pegem Yayıncılık, 7. bs., 2003.
} 
otoritelerin karara müdahaleleri olabilmektedir. Bu müdahaleler genellikle okul yöneticisinin inisiyatifinde olan, yasalarda açıcça ifade edilmeyen ve takdir yetkisinde olan alanlarda olmaktadır. Bu alanlara gri alan denilmektedir. Bu durumda "karar vermede etik" kavramı öne çıkmaktadır. Karar verirken etik kaygıların sürece dâhil edilmesi, yöneticinin etik ikileme düşmesini ifade eder. Etik ikilem; iki veya daha fazla yarışan değerin çekişmesi halini ifade etmektedir. Çatışan bu değerlerden birisi arzu edildiğinde, diğerinin/diğerlerinin göz ardı edilmesi gerekmektedir. ${ }^{8}$ Okul yöneticilerinin işlerini yaparken birçok etik ikilemlerle ve ahlaki buhranlarla karşı karşıya kalmaları normaldir. Yönetim faaliyetlerinin etik davranışlara uygun olarak gerçekleşmesinin yaygınlaşması için bu ikilemlerin kaynağına inilmesi gerekmektedir.

Her türlü organizasyon yöneticilerinde olduğu gibi okul yöneticilerinin de bulunduğu okuldaki tüm davranış ve kararlarında etik ilkelere bağlı kalmaları okulun iklimi, huzuru, başarısı ve tüm paydaşların işyeri mutlulukları için hayati önem taşımaktadır. Yapılan araştırmalar, örgütlerdeki etik iklimin, hem örgütsel güveni hem de çalışanın performansını arttırdığını göstermektedir. ${ }^{9}$ Okul yöneticisi, bireylerin en değerli varlıkları olan çocuklarını emanet ettikleri hayati derecede hassas bir organizasyonun başındaki kişidir. Bu nedenle okul; topluma ulaşmak isteyen, toplumdan talepleri olan her otorite için yüksek bir potansiyel arz etmektedir. Okul yöneticisi, bu konumundan dolayı çeşitli kurum ve otorite ile ilişki içerisindedir. ${ }^{10} \mathrm{Bu}$ farklı kesimlerin okul yöneticisinden değişik beklenti ve istekleri olabilmektedir. Örneğin aileler öğretmen seçme konusunda, siyasi gruplar en çok kayıt alanı dışındaki öğrencilerin kaydının yapılması konusunda, kamu sendikaları üye kazandırma konusunda, dernek ve vakıflar ise okulda gösteri yapma, afiş-ilan asma ve yurtlarında kalan öğrencilerin okula kayıt edilmesi gibi isteklerde bulunmaktadır. ${ }^{11} \mathrm{Bu}$ beklenti ve istekler okul yöneticilerinde bir baskı unsuru haline gelebilmekte, onları sürekli etik ikilemlere itebilmektedir. Bu beklentilerin karşılanamaması durumunda okul yöneticisinin görevde kalma sorunu gündeme gelebilmekte ve bu durum okul yöneticilerinde yoğun bir kaygı üretmektedir. Okul yöneticisinin bu zor durumu Şekil 1'deki okul yönetici etik karar bunalımı modelle ifade edilmeye çalışılmıştır.

Toplumun eğitimle ilgili direk temas noktası okul yöneticisi olmakta, tüm beklenti ve isteklerin odağında milli eğitim müdürlükleri değil, okul yöneticisi bulunmaktadır. Yapılan bir araştırmada, okul yöneticilerinin üstlerinden ve alt ka-

\footnotetext{
${ }^{8}$ Saffet Karayaman, "Yönetimde Duygusal Zekâ, İşyeri Mutluluğu ve Etik Karar İlişkisi: Okul Yöneticileri Üzerinde Bir Araştırma”, Doktora Tezi, Gelişim Üniversitesi, 2019, s.78.

${ }^{9}$ Mustafa Büte, “Etik İklim, Örgütsel Güven ve Bireysel Performans Arasındaki İlişki”, Atatürk Üniversitesi İktisadi ve İdari Bilimler Dergisi, 25 (2011), s.171-192.

${ }^{10}$ Hasan Güneş, "Baskı Grupları ve Okullar”, 7 Şubat, 2018, https://www.kamubiz.com/baski-gruplari-veokullar-makale,428.html.

${ }^{11}$ Zekeriya Ürun ve Asiye Toker Gökçe, “Okul Müdürlerinin Baskı Gruplarının İstekleri ile Başa Çıkma Taktikleri”, Journal of Teacher Education and Educators, 4/1 (2015), s.121.
} 


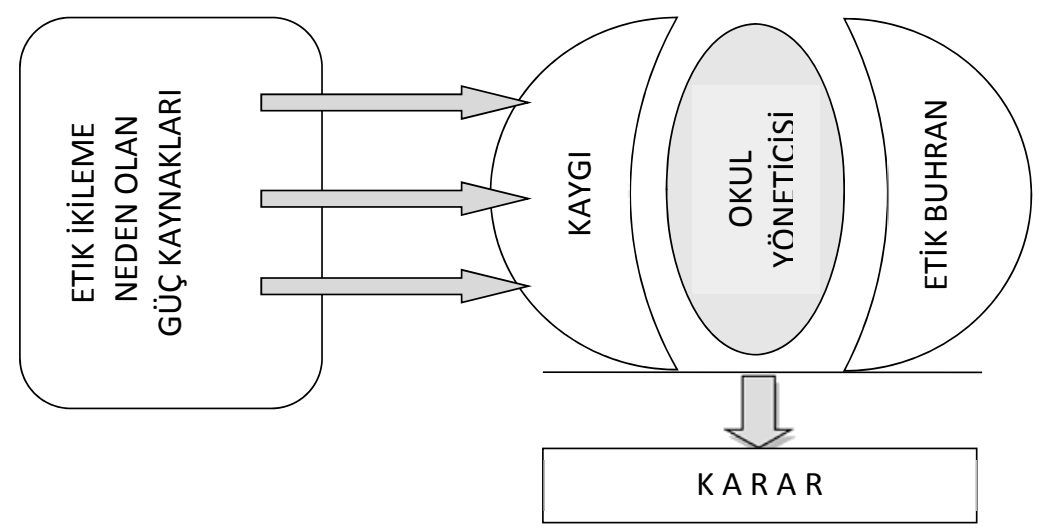

\section{Şekil 1. Okul Yöneticisinin Etik Karar Bunalımı Modeli}

deme paydaşlarından gelen birtakım baskılara hatta mobbinge maruz kaldıkları belirtilmektedir. ${ }^{12}$ Okul yöneticisi ise, çeşitli otoritelerin istediklerini yapmama durumunda ne olacağı kaygısı arasında sıkışmaktadır. Okul yöneticileri üzerinde tasarruf ve yaptırım uygulama gücü olan ilçe milli eğitim müdürlerinin atamalarında, herhangi bir kriterin de olmaması da, bu makamların da birtakım güç odaklarının müdahalesine maruz kalmalarına neden olmaktadır. Ülkelerin gelişmişlik düzeyi arttıkça, milli eğitim müdürleri, belediye başkanlıkları gibi daireler önünde görüşmeyi bekleyen insan yoğunluğu azalmaktadır denilebilir. Normal bir işleyişte, bir talebin cevabı yasada genellikle bellidir ve yöneticiye gidilmesi bu durumu değiştirmeyecektir. Ne yazık ki karar makamlarının kapıları, olacak bir talebin engellenmesi ya da olmayacak bir talebin gerçekleştirilmesi beklentisi ile dolmaktadır. Gerçek medeniyet ölçütü, yasaların herkese eşit uygulanır olmasıyla, sürekliliğiyle ve yöneticileri etik dışına itecek beklentilerin toplumdaki yaygınlığıyla ilgilidir.

\section{Araştırmanın Amacı ve Önemi}

Yönetici işini yaparken, bazı talepler ve baskılar sonucunda etik saha içerisinde kalıp kalmaması konusunda yoğun ikilemlere düşebilmektedir. Türkiye'de okul yöneticiliği alanında yapılan çalışmalar incelendiğinde etik ikilem ve etik ihlallerin temelinde neler olduğu, yönetici karar alırken hangi güç odaklarının etik bunalımlara neden olduğu konusu üzerinde yeterince durulmadığı görülmüştür. Oysa bir sorunu çözmek için öncelikle bu sorunu tetikleyen güçlerin ortaya çıkarılıp bu durumun rehabilite edilmesi ve düzenlenmesi gerekmektedir. Sivrisinekten kurtulmanın yolunun, onları ilaçlamak yerine bataklığı kurutmak olduğu örneğinden hareketle, etik dışı uygulama sonucunda yöneticiye ceza vermekle sorun çözülemeyecektir. Bu tür müdahalelerde kişiye göre uygulamalar, etik ikileme neden olan aynı üst makamın disiplin uygulamalardaki takdir genişliği, muhakkik ${ }^{13}$ atamalarındaki olası keyfilikler, bahse konu etik problem tartışmalarının sürüp gitmesine

\footnotetext{
${ }^{12}$ Durdağı Akan, İsa Yıldırım ve Sinan Yalçın, “Okul Yöneticilerine Aşağıdan Yukarı Doğru Uygulanan Yıldırma (Mobbing) Davranışları”, International Online Journal of Educational Sciences, 5/3 (2013), s.649.

${ }^{13}$ Okullardaki inceleme-soruşturmaları yürütmesi ve raporlaştırması için başka bir okul yöneticisi görevlendirilmektedir. Görevi süresince müfettiş gibi yetkiler verilen bu kişilere muhakkik denilmektedir.
} 
neden olmaktadır. Bu şekilde sorunun kaynağına inilememektedir. Başbakanlık Etik Kurulu Başkanlığı da yapmış olan Sayın Eryılmaz’ın aktarımıyla Konfüçyüs yüzlerce yıl önce bu durumu şöyle ifade etmiştir; “İnsanları sadece ceza ile yönetirseniz, onlar bir daha yanlış yapmazlar; ancak şeref ve utanma duygusuna da sahip olmazlar. İnsanları erdemle ve etik kurallar ile idare ederseniz, o zaman onlar şeref ve utanma duygularına sahip olurlar, hem de doğruyu ve iyiyi yapmaya çalışırlar". ${ }^{14}$ $\mathrm{Bu}$ çalışmanın amacı; okul yöneticilerinin çalıştıkları okul kademesine göre, karşılaştıkları etik ikilemlerin asıl nedenlerine dikkat çekmeyi, etik ikileme iten bu güç kaynaklarının neler olduğunu ortaya çıkarmayı amaçlamaktadır.

Eldeki bu çalışma:

- Okul yöneticileri alanında etik standartların oluşturulmasına katkı sunacaktir.

- Okul yöneticiliğinin profesyonel bir uzmanlık olarak tanımlanmasının gerekliliğini ortaya koyacaktır.

- Çeşitli otorite ve oluşumlarca okul yöneticilerine yapılan müdahalelerin ne denli sakıncaları olduğunu gösterecektir.

- Hangi otorite ve güç kaynaklarının etik kaygılara neden olduğunun belirlenmesine 1 şı tutacaktır.

- Okul yöneticilerinin kararlarının etik kalitesinin daha fazla yükseltilmesi için neler yapılabileceği konularında katkı sağlayacaktır.

Araştırmada elde edilen bulgularının, Milli Eğitim Bakanlığı politikalarının belirlenmesine katkı sağlayacağ 1 düşünülmektedir. Hizmet içi eğitim ihtiyaçlarının belirlenmesi, eğitim yöneticilerinin seçilmesi ve yetiştirilmesi gibi konulara katkı sunacağ 1 değerlendirilmektedir. Bu araştırma bulgularının ayrıca, okul yöneticilerinin çalışma şartları, görevlerini yerine getirirken karşılaştıkları güçlükler, yaşadıkları kaygı sarmalı, karar verirken karşılaşabildikleri baskı ve zorluklar konusunda farkındalık oluşturması ve okul yönetiminde etik ilkelere dikkat çekmesi umulmaktadır. Araştırmacının uzun yıllar okul müdür ve müdür yardımcılığı yapması, uygulamanın içinde olması da araştırmanın gerçekçiliğini, özgünlügünü ve kalitesini arttıran önemli bir unsur olarak değerlendirilmektedir.

\section{Yöntem}

Eldeki bu çalışma, nitel bir araştırma olup, nitel araştırma türlerinden çoklu durum deseni kullanılmıştır. Bu çalışmada, İlkokul, Ortaokul ve Lise okul müdür ve müdür yardımcıları ele alınmıştır. Katılımcılara açık uçlu sorular sorularak, görevlerini yaparken karşılaştıkları etik ikilemlere neden olan otoriteler belirlenip gruplandırılmıştır. TÜBİTAK tarafından belirlenen etik onay ilkelerine göre; Çalışmada 2020 yılından önceki verilerin kullanılması ve etik kurul onayına bağlanacak çalışma türlerinin de dışında olması nedeniyle etik kurul onayından muaf olduğu yazar tarafindan beyan edilir.

\footnotetext{
${ }^{14}$ Bilal Eryılmaz, “Etik Kültürü Geliştirmek”, Türk İdare Dergisi, 459 (2008), s.1-12.
} 


\section{Çalışma Grubu}

Bu çalışma, İstanbul Esenyurt İlçesindeki ilkokul, ortaokul ve liselerde görev yapan, okul müdür ve müdür yardımcıları üzerinde uygulanmıştır. Okulun bulunduğu her yörenin toplumsal dinamikleri, sosyoekonomik yapısı, siyasi fraksiyonu farklı olup, okul yöneticisinden beklentilerin de farklı olacağı düşünülmektedir. $\mathrm{Bu}$ durum araştırmamızın bir sınırlılığıdır. Her ilçeye ve bölgeye genellenemeyecektir. Çalışma, gönüllülük esasına göre gerçekleştirilmiştir. Kişisel bilgilerinin ve iletişim adreslerinin paylaşılmaması konusunda hassas olunmuştur. Katılımcılar kolay ulaşllabilir durum örneklemesi ile belirlenmiştir. Bu örnekleme yönteminin, araştırmanın daha hızlı ve pratik olmasını sağlamaktadır. ${ }^{15}$ Katılımcıların demografik değişkenleri olarak; cinsiyet, yaş, çalıştığı kurum, öğrenim durumu ve alanda çalışma yılları dikkate alınmıştır. Araştırmanın yapıldığı 2017 yılı Nisan Ayında yayınlanan İstanbul örgün eğitim istatistikleri verilerine göre Esenyurt İlçesi örgün ilk, orta ve lise okul sayısı 152 olarak bildirilmiştir. ${ }^{16}$ Katılımcıların \%44'ünün ilkokul, \%36'sının ortaokul, \%20'sinin ise lise okul yöneticisi olduğu görülmektedir. Yine katılımclların \%80'inin erkek $(n=40), \% 20$ 'inin kadın $(n=10)$, yaş ortalamalarının 20-30 aralığında 23 yönetici, $31-40$ aralığında 14 yönetici, $41-50$ aralığında 8 yönetici, 51 yaş üstünde ise 5 yönetici bulunmaktadır. Yönetici olarak çalışma yıllarının ortalamasının ise 0-1 yıllık 13, 1-4 yıllık 20,5-8 yıllık 11 ve 9 ve üstü 6 yöneticinin olduğu görülmektedir. 1-4 aralığında 33 yöneticinin, olduğu bulunmuştur. Ayrıca katılımcıların \%34'inin öğrenim durumu lisansüstü iken, \%66'sının ise lisans mezunu olduğu bulunmuştur. Katılımcıların görev yaptığı okulların \% 80'inin ( $\mathrm{n}=40)$ ikili eğitim, \%40'ının ise $(n=20)$ tekli yani normal eğitim yapan okullarda görev yaptıkları görülmüştür. Araştırmaya katılanların görev yaptıkları okul türleri ile yaş, cinsiyet, mezun olunan okul seviyesi, yöneticilik yılı ve çalışılan okulun öğrenim şekline (ikili eğitim/normal eğitim) göre dağılımları Tablo-1' de sunulmuştur.

Tablo 1. Katılımcıların Okul Türlerine Göre Demografik Dağılımları

\begin{tabular}{|l|l|c|c|c|c|}
\hline \multicolumn{2}{|c|}{} & Illkokul & Ortaokul & Lise & Toplam \\
\hline \multirow{4}{*}{ Cinsiyet } & Erkek & 18 & 15 & 7 & 40 \\
\cline { 2 - 6 } & Kadın & 4 & 3 & 3 & 10 \\
\hline \multirow{4}{*}{ Yaş } & $20-30$ & 10 & 9 & 4 & 23 \\
\cline { 2 - 6 } & $31-40$ & 5 & 6 & 3 & 14 \\
\cline { 2 - 6 } & $41-50$ & 4 & 2 & 2 & 8 \\
\cline { 2 - 6 } & $51+$ & 3 & 1 & 1 & 5 \\
\hline \multirow{4}{*}{ Yöneticilik Süresi } & Lisans & 12 & 13 & 8 & 33 \\
\cline { 2 - 6 } & Lisans Üstü & 7 & 6 & 4 & 17 \\
\cline { 2 - 6 } & & 6 & 5 & 2 & 13 \\
\cline { 2 - 6 } & $1-4$ & 10 & 6 & 4 & 20 \\
\cline { 2 - 6 } & $5-8$ & 4 & 4 & 3 & 11 \\
\hline
\end{tabular}

${ }^{15}$ Ali Yıldırım ve Hasan Şimşek, Sosyal Bilimlerde Nitel Araştırma Yöntemleri, Ankara: Seçkin Yayıncılık, 2006, s.115.

${ }^{16}$ Sevgi Yücel ve İlhan Kakırman, haz., “2016/2017 İstatistik Verileri”, İstanbul İl Milli Eğitim Müdürlüğü, 2017, https://istanbul.meb.gov.tr/meb_iys_dosyalar/2017_04/12163411_2016-2017_Ystatistik_KitabY_Taslak.pdf (erişim 12.03.2019). 


\begin{tabular}{|l|l|c|c|c|c|}
\hline \multirow{2}{*}{ Okulun öğretim şekli } & İkili & 19 & 15 & 6 & 40 \\
\cline { 2 - 6 } & Tekli( Normal) & 3 & 3 & 4 & 10 \\
\hline
\end{tabular}

\section{Veri Toplama Aracı}

Araştırmaya ait veriler standartlaştırılmış açık uçlu soru tekniği ile elde edilmiştir. Bu görüşme yaklaşımı, dikkatlice hazırlanmış ve belirli bir sıraya konulmuş birbirinin devamı şeklindeki soruların, görüşülen her kişiye aynı tarz ve düzende sorulmasını ifade eder. ${ }^{17}$ Görüşme soruları hazırlanırken literatürden faydalanılmıştır. Hazırlanan görüşme sorularının kapsam geçerliliğin sağlanması için, alanda aktif olarak çalışan 5 okul yöneticisinin görüşlerine başvurularak gerçekleştirilmiştir. Yarı yapılandırılmış görüşme formunun ilk bölümünde katılımcılara cinsiyetleri, medeni durumları, yaşları, öğrenim durumları, alandaki toplam çalışma süreleri, çalıştıkları okul kademesi, okulun öğrenim şekli (ikili-tekli) gibi durumlara ilişkin demografik bilgiler sorulmuştur. İkinci bölümde ise "Sizi etik ikilemlere iten, bunlara neden olan güç kaynakları, olgu ve otoriteler / sorunu çözmenizin önündeki engeller nelerdir?” sorusuna yer verilmiştir:

Araştırmanın temel sorusundan sonra görüşmeler sırasında katılımcıların yanıtlarına bağlı olarak alt sorular da oluşturulmuştur. Örneğin etik ikileme neden olan kamu sendikaları, dernek ve vakıfların müdahaleleri olarak ifade eden bir katılımcıya “yaşadığınız bu müdahaleye bir örnek verir misiniz?” diye bir detay ve örnek olay sorusu yöneltilmiştir. Görüşmelerde kişilerin kimliklerini açık edici bilgilerden kaçınılmış ve her katılımcı ile yapılan görüşme yazı ile kaydedilmiştir. Görüşme sonunda alınan notlar katılımcıya okunmuş ve mutabık kalınmıştır.

\section{Verilerin Toplanması}

Araştırmaya ait veriler 2017-2018 eğitim öğretim yılının ilk döneminde toplanmıştır. Görüşmeler araştırmacı tarafından gerçekleştirilmiştir. Görüşmeler katılımcılarla kendilerini rahat hissedeceklerini belirttikleri ortamlarda yüz yüze yapılmış ve her bir görüşme 30-40 dakika arasında sürmüştür. Görüşme sırasında katılımcılara çalışmanın amacı hakkında kısa bilgi verilmiş, gizliliğe önem verileceği ve bilgilerin araştırma amacıyla kullanılacağı konusunda söz verilmiştir. Sorulara geçilmeden önce; etik kavramı açıklanmış ve okul yöneticilerinin kararlar alırken etik ikileme düşmelerine ilişkin örnekler verilmiştir. Etik ikilemler, okul yöneticilerinin uymaları gereken yasal mevzuatın tam olarak değinmediği hususlara ilişkin, gri alan olarak da nitelendirilen konuları içermektedir. Etik ikilemler, okul yöneticisinin daha çok takdir yetkisinde kalan kararlarda ortaya çıkmaktadır. Örneğin okul kayıt bölgesi dışından gelen bir öğrencinin okula kaydının yapılması yasal olarak suç olmayıp, etik açıdan sorunludur. Her kayıt bölgesi dışından gelen talebin karşılanması da mümkün değildir. Bu durum okul yöneticisi mevzuatında gri alan olarak nitelendirilebilir. Bir takım otoritelerin baskısıyla bu talebi yerine getiren yönetici, karşılayamadığı taleplerle birlikte konuyu ele alıp etik ikileme düşmektedir. Bu yöndeki genel örnekler üzerinden etik ikilem kavramı somutlaştırıldıktan sonra görüşmeye geçilmiştir.

\footnotetext{
${ }^{17}$ Yıldırım ve Şimşek, Sosyal Bilimlerde Nitel Araştırma Yöntemleri, s.131-138.
} 


\section{Verilerin Kodlanması}

Araştırmadaki verilerin analizinde öncelikle katılımcıların cevaplarının bulunduğu yazıya dökülmüş hali her bir katılımcı tarafından kontrol ettirilmiş ve onaylattırılmıştır. Toplamda 63 sayfalık Word dokümanı elde edilmiştir. Daha sonra katılımcılardan elde edilen tüm veriler incelenerek anlamlı bölümlere ayrılmış ve kendi içinde anlamlı bütünler oluşturan bu bölümlere isimler verilerek kodlanmıştır. Tüm veriler bu şekilde kodlandıktan sonra kod listesi oluşturulmuştur. Ana temaların belirlenmesinde, ilgili alan yazının yanı sıra bulgular da ortaya çıkan kavramlarda etkili olmuştur. İlk önce 50 katılımcı arasından seçilen 10 katılımcının verileri, araştırmacı dışında ayrı bir uzman öğretim görevlisi tarafından da değerlendirilmiş; iki veri işleyicinin tutarlılığına bakılmıştır. Güvenirlik için her iki uzman tarafından yapılan kodlamalar üzerinde Güvenirlik= Görüş Birliği/ Görüş Birliği+ Görüş Ayrılığ 1 X 100 formülü uygulanmıştır. ${ }^{18}$ Yapılan hesaplama sonucunda tutarlılık \%95 bulunmuştur. Tutarlılığın \%70 veya daha üstü olması yeterli görüldügünden veri analizi açısından güvenirlik sağlanmıştır. Daha sonra verilerin kategorilere dönüştürülmesi işlemi, araştırmacı ve uzman öğretim üyesi tarafından ortak bir görüşe varana kadar tartışılarak gerçekleştirilmiştir. Örneğin; okul kayıt bölgesi dışından bir öğrencinin kaydının yapılması için belediye başkan yardımcısının araması örnek olayı; "yerel yönetimler ve siyasi grupların beklentileri" kategorisinde değerlendirilmiştir. Araştırmada toplanan veriler nitel araştırma yöntemlerinden betimsel ve içerik analizi yöntemiyle çözümlenmiş; verilerin kategorileştirilmesi sürecinde tümevarım yöntemi izlenmiştir. Yani; daha önceden belirlenen temalar kullanılmamış; metinlerdeki ortak noktaların, temaların ve kategorilerin belirlenmesine çalışılmıştır. Bu tema ve kodlar çerçevesinde araştırmanın bulguları incelenmiştir. Tüm örnekler, bu şekilde 7 ana grupta toplanmıştır. Katılımcıların isimleri gizlenmiş ve K1, K2, K3... Şeklinde sırası ile kodlanmıştır.

\section{Bulgular}

Araştırmaya katılan okul yöneticilerine; "Size göre işinizle ilgili bir karar verirken etik ikilemlere düşmenize neden olan ve bunları çözmenizi engelleyen olgu ve otoriteler nelerdir?” sorusuna verilen yanıtlar incelenmiş; cevaplar ortak temalar altında toplanıp kategorileştirilmiştir. Okul yöneticilerinin çalıştıkları kurum türlerine göre belirlenmiş olan kategorilerden her birine ait bir olayla karşılaşma sıklığ Tablo 2'de sunulmuştur.

Tablodan da görüleceği üzere; İlkokul yöneticilerine göre, etik ikileme iten baskı ve güç kaynağı olarak sırasıyla; velilerin eğitimsizliği ve sosyoekonomik seviyesi; yerel yönetimler, siyasetçiler ve sivil toplum örgütleri, dernek ve vakıfların beklentileri; üst makamların popülist uygulamaları; amirlerin yetkinlik ve becerileri eksikliklerinden kaynaklı durumlar; siyasi politikalar ve son olarak okul içi personel güç dinamikleri olarak ortaya çıkmıştır. Ortaokul yöneticileri ise sırasıyla, yerel yönetimler, siyasiler ve sivil toplum örgütleri, Sendika ve dernek ve vakıflar; üst makamların popülist uygulamaları; amirlerin yeterlilik ve becerileri olarak sıralamışlardır. Lise okul yöneticileri ise yoğun olarak sırasıyla, sendika, dernek ve vakıfların

${ }^{18}$ Ahmet Saban, "Metaphors about School”, Educational Administration: Theory and Practice, 14/3 (2008), s.459-496. 
taleplerini; yerel yönetimler ve siyasilerin taleplerini; siyasi politikaları, devamında ise üst makamların popülist uygulamalarını göstermişlerdir.

Tablo 2. Okul Yöneticilerini Etik İkileme İten Baskı ve Güç Kaynaklarının Okul Türlerine Göre Dă̆ılımı

\begin{tabular}{|l|c|c|c|c|c|c|}
\hline \multirow{2}{*}{$\begin{array}{c}\text { Okul Yöneticisini Etik İkileme İten } \\
\text { Güç Kaynakları }\end{array}$} & \multicolumn{2}{|c|}{ Ilkokul } & \multicolumn{2}{c|}{ Ortaokul } & \multicolumn{2}{|c|}{ Lise } \\
\cline { 2 - 8 } & S1klık & $\%$ & S1klık & $\%$ & S1klık & $\%$ \\
\hline Siyasi politikalar & 2 & 4 & 3 & 6 & 2 & 4 \\
\hline Üstlerin yeterlilik ve beceri düzeyleri & 2 & 4 & 2 & 4 & 3 & 6 \\
\hline Üst makamların popülist uygulamaları & 2 & 4 & 3 & 6 & 3 & 6 \\
\hline Sendika, dernek, vakıf talepleri & 4 & 8 & 4 & 8 & 4 & 8 \\
\hline Veli kaynaklı sorunlar & 4 & 8 & 1 & 2 & 0 & - \\
\hline Yerel yönetici ve siyasilerin talepleri & 3 & 6 & 4 & 8 & 2 & 4 \\
\hline Okul içi personel güç dinamikleri & 0 & - & 1 & 2 & 1 & 2 \\
\hline
\end{tabular}

Okul yöneticilerini etik dışı karar almaya zorlayan baskı ve güç kaynakları olarak; Her üç okul kademesinde de;

1. Sendika, dernek ve vakıfların talepleri,

2. Yerel yönetici ve siyasilerin talepleri,

3. Üst makamların popülist uygulamaları; en üst sırada belirtilmiştir.

İlkokullarda veli kaynaklı sorunların öne çıkmasının nedeni; ilkokul velilerinin okulla sürekli iletişim halinde olmaları olarak yorumlanabilir. Liselerde yasal eksikler ve sorunlardan, ilkokullarda ise okul içi personel güç dinamiklerinden bahsedilmemiştir. Bu sonuç, Urun ve Gökçe'nin çalışmasıyla da uyumluluk göstermektedir. ${ }^{19}$ Çalışmamızda elde edilen sonuçların, literatürle örtüştüğü görülmektedir. ${ }^{20}$

Katılımcıların görüşlerinden bazı örnekler, ilgili tema başlığı altında aşağıda sunulmuştur;

\section{Sendika, dernek, vakıf talepleri;}

Son zamanlarda pek çok dini içerikli sivil toplum örgütleri, dernek vb. kuruldu. Her biri de siyasetten destekli. Bunlar güzel şey ancak, siyaset desteğini bir tehdit olarak kullanıyorlar. Dini de paravan kullananlar var bence. Mesela vaktimizin çoğunu veliden çok bu derneklerin öğrenci etkinlik, proje adı altındaki göstermelik faaliyetlere ayırıyoruz. İçi dolu olsa sorun yok ama, çoğu bir şey yapıyormuş gibi görünme reklamasyon. Okulumuzu kendi reklamları için kullanıyorlar. Mantıklı bir şey söylesek de hemen belirli yerlere muhalifmiş gibi ismimiz veriliyor ve amirlerimiz arayabiliyor. Koltuğunda

\footnotetext{
${ }^{19}$ Urun ve Gökçe, “Okul Müdürlerinin Baskı Gruplarının İstekleri ile Başa Çıkma Taktikleri”, s.105, 125.

${ }^{20}$ Kenan Özcan, "Çevresel Baskı Gruplarının Okul Yönetimine Etkileri (Adıyaman İli Örneği)", E-International Journal of Educational Research, 5/1 (2014), s.88-113; Hüseyin Gül, "Çevresel Baskı Gruplarının Okulun Genel İşleyişine Etkileri (Kocaeli-İzmit Örneği)”, Kocaeli Üniversitesi Sosyal Bilimler Enstitüsü Dergisi, 11/1 (2006), s.73; Urun ve Gökçe, "Okul Müdürlerinin Baskı Gruplarının İstekleri ile Başa Çıkma Taktikleri”, s.105-125; Erdal Toprakçı, "Güç Merkezleri Açısından Okulun Örgütsel Farklılıkları”, Kuram ve Uygulamada Eğitim Yönetimi, 26 (2001), s.277-287.
} 
kalman için ne deniyorsa yapacaksın. Etik biraz lükse kaçıyor. (K-12).

Geçen yıl sendika temsilcileri okula gelmişlerdi. Benimle birlikte öğretmenler odasına girip tanıtım yapmak, öğretmenlerle sohbet etmek istediler. $\mathrm{Bu}$ sendika yetkili sendikaydı ve müdür atamalarında istediğini yapıyordu. Hatta listeleri sendika yönetimi belirliyordu. Ben sendikacılara hayır diyemedim. Kendilerine düşman görmesinler diye istemeyerek de olsa öğretmenler odasına onlarla girdim. Çoğu öğretmen benim onları desteklediğimi, taraf tuttuğumu filan zannettiler. Tarafsızlığıma gölge dişti. Etik olarak içime sinmese de geleceğim için mecbur kaldım. (K-24).

Ben sendikacıların öğretmenleri derslerinden alıkoyduğunu görüyorum. Geçen hafta sendikacılar öğretmenler odasına girdiler ve ders zili çalmasına rağmen toplantıyı sürdürdüler. Öğretmenler derslerine geç kaldılar. Onlarla aram bozulmasın diye müdahale de edemedim. İçime de sinmedi ama yapacak bir şey yok. Kabak bana patlasa maalesef koruyanımız yok. (K-30).

Sendika, dernek ve vakıf taleplerinin oluşturduğu baskının okul yöneticilerinde neden olan etik ikilemlerin, tüm okul türlerinde de yoğun olarak görüldügü bulunmuştur. Özellikle sendikaların okul müdürleri üzerinde baskı unsuru oluşturdukları sık ifade edilen bir durum olmuştur.

\section{Yerel yönetici ve siyasilerin talepleri;}

Bence bu konudaki en büyük engel belediyenin okulların her işine müdahale etmesidir. Belediye yöneticileri, vatandaşa şirin gözükmek için çözeceğim diyor, müdür arıyor veya bir not yazarak veliyi okula yolluyor. Okul yöneticisi yasa müsaade etmediği için yapmıyor ancak halk nazarında siyasetçi iyi, bürokrat kötü oluyor... (K-2).

Kayıt dönemlerinde belediye başkan yardımcılarının bize veli yollamasından bunalıyoruz. Muhtar bile bu işi yap, arkamda reis var diyor. Oysaki bizler yasaya uygun davranmak zorundayız. Vatandaşa mavi boncuk vererek, belki bir yolu vardır diye alıştırılıyor. Yasalara da güven kalmıyor. $(\mathrm{K}-32)$.

Mevzuatta her öğrenci ikametgahının olduğu yerdeki okula kayıt yaptırır diyor ancak vatandaş sahte adres gösterip başka okullara yaptırıyor. Bunu denetleyen ve engelleyen muhatabı da bulamıorsunuz. Yapanın yanına kar kalıyor. Sonrasında diğer velilerle okul yönetimi karşı karşıya geliyor ve toplum gözünde itibar kaybediyorsunuz. (K-22).

Yerel yönetici ve siyasilerin okulların ihtiyaçlarını gidermeye yardımcı oldukları ve okullardan bir takım taleplerde bulundukları görülmektedir. Halkın teveccühü ile varlığını sürdüren siyasetçilerin ve yerel yöneticilerin, aynı halktan gelen okullarla ilgili bir takım istek ve ricalara duyarsız kalması da beklenemez. Bu durum araştırma verilerinde de görülmektedir. 


\section{Üst makamların popülist uygulamaları;}

Yeni il müdürümüz gelince iş yükümüz çok arttı. Zaten mevcut iş yükünü zor yürütebiliyorduk. Şimdi birde onlarca proje konusu geldi. İl müdürlügünde öğrenci yok, maaş bekleyen personel, bunlara para bulmak için karar kara düşünme derdi yok. Sürekli proje fikri üretiliyor. Bizim okulumuzun önceliği aslında çok farklı. Sadece bir personelimizi bile bu proje yazışmaları için görevlendirmemiz gerekiyor. Bana göre il müdürlügü çalıştığı algısını bol bol proje üreterek ifade etmek istiyor. Bizim önceliğimiz ise üç bine yakın (3000) öğrencimizi sabahçı ve öğlenci olarak, sağ salim ailelerine teslim edebilmek. Her gün en az bir öğrencimizin bir çarpışma, düşme kırılma yarılma kanama kazası veya kaybolma olayı oluyor. Bu kargaşada bir müdür yardımcımız sırf proje yazılarıyla uğraşıyor ne yazık ki. (K-7).

Okulumda temizlikçi sayısı yetersiz. Bütçe yok, para yok. Hizmetli almam için veliden bağış istemem lazım. Ancak siyasiler sanki her şey mükemmelmiş gibi, okula para vermeyin, bağış isteyen müdürü şikâyet edin diye vatandaşa mavi boncuk dağıtıyorlar. Para istesem mi, istemesem mi, ne yapacağımı bilmiyorum. İstemesem okul berbat olacak, bu da içime sinmiyor. (K$8)$.

Üst yöneticilerin, özellikle il milli eğitim müdürlerinin, kendilerini atayan sıralı makamlara ve siyasi iradeye karşı başarılı bir profil sunmak için bir takım popülist uygulamalarda bulundukları sıkça ifade edilmiştir. Her gelen üst yöneticinin yeni projelere giriştiği; yeni uygulama ve bunların toplantı, tanıtım gibi faaliyetlerine ağırlık vermelerinin okullara çeşitli olumsuz yansımalarının da olduğu ifade edilmektedir. Yine okullara ödenek gönderilmeyişinin üst makamlarca halka dürüstçe ifade edilmeyip okul yöneticilerinin bu sorun karşısında yalnız bırakılmasının onları etik ikileme ittiği görülmektedir.

\section{Veli kaynaklı sorunlar;}

Velilerimiz çok cahil ve üst makamlar tarafından şımartılmış durumda. Telefonu olan, en ufak bir sorunda okula gelmek yerine 147'yi arıyor, BİMERE, CIMMERE yazıyor ve saçma sapan şikâyet ediyor. Hâlbuki bir suç yok. Mesela neden okul ikili eğitim yapıyor diye yöneticisi şikâyet ediyor. Oysa müdür sadece bir uygulayıcı. Cevap verirken devlet yeterince okul yapmiyor diye yazamıorum. Mecburen eveleyip geveleyip usulüne uygun bir cevap yazıyorum. Tabii bu durum içime de sinmiyor. (K-11).

Suriyeli veliler çok sık gelmeye başladı. Sınıflar çok kalabalık. Bazı sorunlu velileri almak istemiyorum. Mevcudu az olan başka okullara elimden geldiğince yönlendirmeye çalışıyorum. Bu yönlendirmeler aslında doğru değil ama ne yapabilirim ki. Okulumuzu düşünmek zorundayız. (K-39).

Hesap verebilirlik kavramının sınırsız özgürlük anlayışıyla kullanılmasının pek çok okul yöneticisinin zarar görmesine neden olduğu görülmektedir. Yine kontrolsüz sığınmacı akının meydana getirdiği sorunlar, okulların kalabalık olması, okul yöneticilerinin veli ilişkisinde bir takım etik kaygılar doğurmaktadır. Velilerin eğitim 
düzeylerinin düşüklüğü, okul yöneticilerine karşı olumsuz algıları nedeniyle okul yöneticilerinin kendilerine korumayı önceleyici şekilde davranmak zorunda kaldıkları, ancak bunun etik ikilemlere neden olduğu da rapor edilmiştir.

\section{Üstlerin yeterlilik ve beceri düzeyleri;}

Bizde sorunlu bir öğrencimiz var. Yandaki ortaokula nakil olması gerekiyor. Aileyi de ikna ettik ama ilçe müdürümüz öğretmenlikten ilçe müdürlüğüne atandığı için işleyişi ne yazık ki bilmiyor ve risk almaktan çekiniyor. Birkaç kez anlatmayı denedim ama başaramadım. Aman sorun gitmesin diye okul değişikliği sürecine hiç girmememizi istedi. Ben de uyma kararı aldım. Yoksa bana sıkıntı olacaktı. (K-21).

Eğitim yönetiminde mevki yükseldikçe daha fazla donanımlı, deneyimli, kariyer ve liyakat kavramları paralelinde niteliği artan yöneticilerin görev alması beklenmektedir. Ancak Türkiye'de okul yöneticiliği de yapmayan bir öğretmenin ilçe mili eğitim müdürü olduğu örnekler görülmektedir. 2019 yılı Sayıştay raporu da bunu doğrulamaktadır. ${ }^{21}$ Niteliksiz yöneticilerin yetersizlikleri, okul yöneticileri üzerinde ölçüsüz bir baskı oluşturmakta ve onları etik ikileme itmektedir.

\section{Siyasi politikalar;}

Son zamanlarda Suriyeliler yoğun olarak gelmeye başladı. Ancak bunlarda kayıt bölgesi uygulaması yok. Yani normal vatandaş çocuğunu evine yakın okula yazdırmak zorunda iken bunlar istediği okula yazdırabiliyor. Bu durumda kendi vatandaşımıza hayır dediğimizde kötü olan biz oluyoruz. $\mathrm{Ne}$ yapacağımı bilemiyorum. (K-26).

Burada siyasi politikaların yanlış olup olmadığı bir tartışma konusu değildir. Bazı politik uygulamaların, etik ikileme temel olan bir güç kaynağı olarak görülmesi söz konusudur. Kitlesel olarak fayda sağlayacak bir politikanın okuldaki bir veli tarafından anlaşılıp anlaşılmaması ya da farklı dinamiklerden kaynaklı tali sorunların okul yöneticisinde oluşturduğu ikilemin ifade edilmesinden ibarettir. Okul yöneticisi arzu ettiği, ya da evrensel doğrularla kararlar alıp uygulama özgürlüğüne sahip değildir. Mevcut siyasi gücün en uçtaki sözcüsü ve temsilcisi konumundadır. Bu çerçevede kalıp kalmadığ ile uygulamak zorunda olduğu arasında bir ikilem halindedir.

\section{Okul içi personel güç dinamikleri;}

Katılımcılar örneklerinde "bizde 20 yıldan fazla aynı okulda görev yapan öğretmen var, artık okulu sahiplenmişler. Onların çıkarlarına dokunan bir karar almaktan çekiniyorum. Onları karşıma almayı asla istemem." (K-13, K-44) ifadelerini kullanmışlardır. Bu temadaki örneklemlerde öne çıkan ayrıntı; uzun yıllar aynı okulda görev yapan çok sayıda öğretmenin okul yönetiminde önemli bir etken olmasıdır. $\mathrm{Bu}$ durumun çeşitli sorunlara neden olduğu, değişime direnç oluşturduğu ve okul

21 "Liyakat Şartlarını Taşımayan Müdür Atamaları Sayıştay Raporunda", Ajanskamu.net internet sitesi, 6.10.2020, https://www.ajanskamu.net/meb/liyakat-sartlarini-tasimayan-mudur-atamalari-sayistay-raporun da-h111139.html. 
yöneticilerinin karar alırken etik ikileme iten bir baskı unsuruna dönüştüğü vurgulanmıştır.

Okul müdürleri bir okulda 4 yıllığına görevlendirilmektedir. Ancak öğretmenlerde rotasyon bir türlü uygulanamamıştır. Öğretmenlere de rotasyon uygulanması halinde; okullarda uzun yılar görev yapmanın getirdiği çıkar ilişkisi sarmalı ve profesyonelliği gölgeleyen aşırı sahiplenme davranışlarının azalacağı ve eğitim organizasyonlarındaki pek çok kronik sorunun kendiliğinden çözüleceği söylenebilir. Öğretmene rotasyon uygulaması aynı zamanda okullarda personel hareketini arttırarak okullarda bir yenilenme ve hareket sağlamanın yanında, görev yerleri bakımından fırsat eşitliğini arttıracaktır.

\section{Yazarın Görüşü}

Katılımcıların, okul yöneticilerini etik ikileme iten güç kaynaklarını ortaya çıkarıcı örnek olaylar sundukları görülmektedir. Araştırmacının da okul müdürü olması, çalışmanın güvenirliğini arttırıcı bir unsurdur. Uygulamanın içindeki araştırmacıların daha verimli sonuçlar elde ettikleri ve bu tür çalışmaların daha değerli olabileceğine dikkat çekilmektedir. ${ }^{22}$ Yine katılımcı sayısının nitel çalışmalara göre fazla olması araştırmamızın güvenirliğini arttıran diğer bir unsurdur. Öte yandan, etik çalışmalarda örnek olay yönteminin kullanılması daha yararlı görülmektedir. ${ }^{23} \mathrm{Ka}-$ tılımcıların anlatımlarının, örnek yaşanmışlıklarının amaca uygun mahiyette oldukları; okullarda yaşanan yönetim süreçleriyle uyumlu oldukları görülmüştür. Verilen örnek olayların, irdelenen konu ile uyumlu ve tam ifade eder nitelikte olduğunun, aynı zamanda okul müdürü olan araştırmacı tarafından belirtilmesi önemli bir husus olarak değerlendirilmektedir.

\section{Tartışma, Sonuç ve Öneriler}

Yapılan araştırmanın bulguları aşağıdaki şekilde yorumlanmış ve öneriler getirilmiştir. Toplanan verilerin anlamlandırılmasının, çıkarımlarda bulunulmasının, son aşamada neden sonuç ilişkileri ile yorumlanmasının araştırmanın en önemli ve en faydalı bölümü olduğu belirtilmektedir. ${ }^{24}$

Okul yöneticilerinin; sendika, dernek vakıf siyasiler ve yerel yöneticilerin taleplerine olumsuz cevap vermesi onlarda kaygı yaratmaktadır. Görevini sürdürmesinin, bu paydaşlarla uyumlu olmasına bağlı olduğu söylenebilir. Okul yöneticilerinin karşılaştıkları etik ikilemlerin kaynağı olarak okul dışı çevrenin etkisi yoğun olarak belirtilmiştir. ${ }^{25}$ Okul yöneticiliğin kadroya bağlanmayıp; öğretmenlere verilen ikinci görev olması, dolayısıyla bir sürekliliğinin ve güvencesinin olmaması, okul yöneticilerinin güçlerini zayıflatmakta ve etik dairede kalmalarını zorlaştırmaktadır. Üst makamların ve bahsedilen otoritelerin masum gibi görünen taleplerinin

\footnotetext{
${ }^{22}$ Karayaman, "Yönetimde Duygusal Zekâ, İşyeri Mutluluğu ve Etik Karar İlişkisi: Okul Yöneticileri Üzerinde Bir Araştırma", s.113.

${ }^{23}$ Saffet Karayaman, "Okul Yöneticilerinde Duygusal Zekâ ve Etik Karar Verme İlişkisi”, Turkish Studies Education, 15/4 (2020), s.2748.

${ }^{24}$ Yıldırım ve Şimşek, Sosyal Bilimlerde Nitel Araştırma Yöntemleri, s.26.

${ }^{25}$ Urun ve Gökçe, “Okul Müdürlerinin Baskı Gruplarının İstekleri ile Başa Çıkma Taktikleri”, s.107.
} 
yönetici üzerinde son derece kaygı yarattığı katılımcı görüşlerinden anlaşılmaktadır. Okul müdürlügünün idari hizmetler sınıfı kadrosuna bağlanıp güvence altına alınmasının okul yöneticilerini dış baskılara karşı güçlendireceği ortadadır. Bu durumda onların etik karar verme düzeylerinin artacağ

Katılımcılar tarafından sıklıkla belirtilen; okul yöneticileri etik dışı karar almaya zorlayan baskı ve güç kaynağı; üstlerin yeterlik ve becerileri konusu olmuştur. Yapılan bir araştırmada da, etik davranışları etkileyen faktörlerin başında üstlerin davranışları olduğu bulunmuştur. ${ }^{26}$ Katılımcıların tamamına yakınının, üstlerin olumsuz değerlendirme yapmasından korktuğu, en ufak bir çatışmada görevinde kalamama kaygısı taşıdıkları anlaşılmaktadır. Bununla ilgili katılımcıların söylediklerinden bazıları şu şekildedir;

Belediye başkan yardımcısı, bir öğrencinin anasınıfına ücretsiz kaydı için beni aradı. Hâlbuki daha çok ihtiyacı olan var, biliyorum. Emrivaki bir şekilde talimat verdi. İlçe yöneticilerinin atanmasında da yerel siyasiler etkili. Polemiğe girsem, görev süremi uzatmayacaklar, ya da uyduruk soruşturma açıp yıpratacaklar... Mecburen adamı olanın işini görmek zorunda kaldım. (K-5).

İlçe yöneticimiz daha önce bir sendika başkanıydı. O Sendikadan olmayan ancak başarılı bir öğretmeni müdür yardımcısı olarak görevlendirdik. Ancak ilçe müdürümüzün sendikasının yöneticisi gelip bu arkadaşın kendi sendikasına geçmesini istedi. Geçmezse mülakatta eleneceğini, bunu iletmemi söyledi. Arkadaşa bu yönde telkinde bulunmadım. Kendisi de sendikasını değiştirmedi. Mülakatta komik bir puan verip elediler. (K-17).

Türkiye'de okul yöneticiliği profesyonel bir görev olarak ele alınmamaktadır. Bu kadar sorumluluk yüklenen okul yöneticiliği, öğretmene verilen ikinci görev olarak uygulanmakta olup, 4 yıllık süre ile görevlendirilmekte, tayin istediğinde de yöneticiliği düşmektedir. ${ }^{27}$ Okul yöneticileri gün içinde oldukça karmaşık, iç içe girmiş ve farklılık arz eden işlerle uğraşmak zorundadırlar. Aslına bakılırsa, büyük bir kısmının da eğitim öğretim kategorisinde olduğu söylenemez. Yaptıkları işler birçok görev kapsamına girebilmekte olup bunların düzenli ve bir rutini de yoktur. ${ }^{28}$ Örneğin aniden tıkanan bir kanalizasyonun açılması için mesai dışı çalışan pek çok okul yöneticisi vardır. Tüm bunların yanında, okullara ödenek gönderilmemesi, müdür ve müdür yardımcısı atamalarında nepotizm tartışmaları, ${ }^{29}$ kalabalık sınıflar, ikili eğitim gibi sorunlar okul yöneticisinin işinin ne kadar zor olduğunu ortaya koymaktadır. Ayrıca, okul yöneticileri üzerinde tasarruf yetkisini elinde bulunduran, bir üst karar mercii olan ilçe milli eğitim müdürlerinin atamalarında ayırt edici bir kriterin olmayışı, var olan kriterlere de uyulmaması, okul yöneticilerini evrensel ve hukuksal zeminden ziyade kişi ve siyasilere bağlılığını teşvik etmektedir. Bu

\footnotetext{
${ }^{26}$ Zümrüt H. Tosun ve İlke Oruç, “İnsan Kaynakları Yönetiminde Etik Dışı Davranışlar ve Yönetimi: Bir İşletmenin Personel Yönetmeliği İçerik Analizi”, İs Ahlakı Dergisi, 5/10 (2012), s.178.

27 "Millı̂ Eğitim Bakanlığı Eğitim Kurumlarına Yönetici Görevlendirme Yönetmeliği”, Resmi Gazete, sayı: 30455, 21 Haziran, 2018, https://www.resmigazete.gov.tr/eskiler/2018/06/20180621-8.htm.

${ }^{28}$ Turan ve Yalçın, “Okul Yöneticilerinin Yaptığı ve Yapmak İstediği İşler ile İş Doyumları Arasındaki İlişkinin İncelenmesi”, s.28.

${ }^{29}$ İnayet Aydın, Eğitim ve Öğretimde Etik, Ankara: Pegem Akademi, 2016, s.79.
} 
durum paydaş kabulünde de sorunlara yol açmaktadır.

Uzun yıllar aynı okulda görev yapan öğretmenlerin, değişime dirençleri de çalışmamızda ifade edilmiștir. Merkezi ve popüler okullarda 20- 30 yıl veya daha fazla kalan öğretmenlerin olduğu bilinmektedir. Buna karşın okul yöneticileri 4 yıllığına görevlendirilmektedir. Bu durum değişime direnç sorununun sıklıkla yaşanmasına sebep olmaktadır. Aynı zamanda yeni kadroların sirkülasyonunu engellemekte, öğretmen temelinde firsat eşitliğinin önünde bir engel olarak görülmektedir. Uzun yıllar aynı okulda görev yapan öğretmenlerin de okul yönetiminin kararlarında bir baskı unsuru oluşturduğu söylenebilir. Okullarda çalışan personelin işletme körlüğü, değişime direnç gibi olumsuzlukların azaltılması için; belirli bir süre aynı okulda çalışan öğretmenin mutlaka rotasyona tabi tutulması gerektiği değerlendirilmektedir.

Özetle; Okul yöneticiliğinin, öğretmene verilen ikinci bir görev olup bir kadroya bağlanmamış olması, görev süresinin de sınırlı olması; okul yöneticilerinin işyerindeki gündelik kararlarını oldukça etkilediği söylenebilir. Bu durum, okul yöneticilerini dış otorite müdahalelerine karşı etik alanda durabilme güçlerini zayıflatmaktadır. Yukarıda da belirtildiği gibi, okul müdürlerinin; kadrolu değil de, görevlendirme olarak istihdam edilmelerinin, onlarda çeşitli kaygılara neden olması doğal bir durumdur. Bu çalışma aynı zamanda okul yöneticilerine yönelik dış otoritelerin müdahalelerine, okul yöneticisi görevlendirme ve görevde kalma usullerine, okulların ödenek sorunları gibi güncel problemlere de dikkat çekmektedir. Okul yöneticilerinin verdiği kararın etik olup olmadığı sorgulanırken, okul yöneticisinin nasıl bir etik ikilem kıskacında oldukları göz ardı edilmemelidir. Okul yöneticileri, sorumluluklarının fazla ancak yetkilerinin az olması gibi nedenlerle etik dışı davranışa yöneltilmektedirler. ${ }^{30}$ En başında, okulların giderlerini karşılamak için mali kaynak bulmak zorunda kalmaktadırlar. Okul yöneticilerinin yetkilerinin arttırılması, okullara yeterli maddi kaynak aktarılması sağlanarak okul yöneticilerini etik dışılığa iten nedenler azaltılmalıdır.

Türkiye'deki okul yöneticilerinin karşılaştıkları etik ikilemleri çözümleyebilmeleri ve aldıkları kararların etik kalitesinin arttırılması için;

1. Okul yöneticiliğinin kadrolarının eğitim öğretim hizmetleri sınıfından yönetim hizmetlerine alınıp bir uzmanlığa dönüştürülmelidir.

2. Okul yöneticileri, üzerlerinde baskı kuracak ya da devlete aidiyetin önüne geçecek her türlü cemiyet sendika vb. aidiyetlerden uzak tutulmalıdır. Herhangi bir cemaat, cemiyet veya sendikanın, okul yöneticisi üzerinde kariyerini etkileyecek bir kanıt olmasının önüne geçilmesi gerekmektedir. Bu tür güç kaynaklarının müdahalesine karşı güvence altına alınmalıdır.

3. İlçe milli eğitim yöneticilerinin cemiyet, sendika vb. aidiyetlerinin olmaması yasal olarak düzenlenmelidir. Atamalarda sadece devlete bağlllı̆̆ın kabul gördüğünün uygulamalarda gösterilmesi çok etkili olacaktır.

\footnotetext{
30 "Okul Yönetiminde Etik / Prof Bilal Eryılmaz", Öncü Yöneticiler internet sitesi, 27 Aralık, 2017, http://www.oncuyoneticiler.com/yonetici-sohbetleri/okul-yonetiminde-etik-prof-dr-bilal-eryilmaz/2017.
} 
4. Okul yöneticilerine çok zorunlu olmadıkça soruşturma yoluna gidilmemesi, soruşturma sonucu aklanan yöneticiyi şikâyet eden hakkında ilgili mercilerce bizzat işlem tesis edilmesi gerekmektedir. Soruşturma ile yöneticilikten alınma uygulaması kaldırılmalıdır. Müdürü istemeyen bir şahsın 50 şikâyet iddiasından 49 tanesi gerçek dişı olsa, yalnızca bir tanesi doğrulansa bile müdüre cezalar verilebilmekte, yöneticilikten alınabilmektedir. Ancak ne yazıktır ki, 49 iddianın uydurma olduğu görülüp; bu süreçte bir kasıt olduğu düşüncesiyle konu ele alınmamakta, yapanında yanına kar kalmaktadır. Kısaca okul müdürünü "yemek" sıradan bir iş haline gelmiştir denilebilir.

5. Bir personeliyle sorun yaşayan yöneticiye, karşılıklı iki çalışanın anlaşamaması olarak bakılmamalıdır. Müdürlük makamı göz ardı edilmemeli, yani yönetim sorumluluğunun paralelinde bir anlayış oluşturulmalıdır. Çünkü müdür bir (1) tane ve uhdesindeki personel sayısı onlarcadır. Her personeli memnun etmek mümkün olmadığı gibi, okul amaçlarının gerçekleştirilmesini sağlayacak denetim görevinin yapılmasını da imkânsızlaştıracaktır. Bu tarz yaklaşımlar, okul yöneticisinin risk alarak çalışmasını engellemektedir. Okul yöneticisi görevini yaparken sadece görevinde kalmayı öncelemek, geleceğini düşünmek zorunda kalmaktadır. Bu durumun insani bir refleks olduğu unutulmamalıdır. Dolayısıyla okul, eğitim, etik gibi hususlar ikinci planda gelmektedir.

Belirtilen tedbirlerle, okul yöneticilerinin etik karar verme güçleri arttırılabilir. Okul yöneticilerin hizmet içi eğitimlerle etik duyarlılıklarının arttırılması tek başına anlam ifade etmeyeceğinden, dış paydaş gruplar için de, (sendikalar, dernek ve vakıflar, siyasiler gibi) etik standartlar oluşturulması, yasal düzenlemelerin yapılması, var olan yasaların kararlılıkla uygulanması gerekmektedir. ${ }^{31}$ Devlet işleyişinde tüm kurumlar birbirleriyle ilişki içerisindedir. Bu nedenle, siyasi iktidarların, etik konusuna samimiyetle önem vermeleri önem arz etmektedir. Etik konusunun özellikle merkezden yerele doğru her kurumda yaygınlaştırılması sağlanmalıdır. Tüm kamu yöneticilerinin tanıdığı tek güç kaynağı yasalar olmalıdır. Her kademedeki kamu yöneticisinin yasalara ve devlete sadakatinin, her türlü cemaat, cemiyet, sendika vb. aidiyetlerinden daha önemli olduğu topluma yerleştirilmelidir.

Etik Kurul Onayına Dair Not: Çalışmadaki veriler 2020 yılı öncesine ait olup, TR Dizin Değerlendirme Kriterleri etik kurul onayı şartı 2020 yılı ve sonrası araştırma verilerini kapsadığından, çalışmamıza dair etik kurul onay zorunluluğu bulunmadiğ 1 değerlendirilmiştir.

\section{Teşekkür}

Araştırmaya katılarak okul yöneticilerinin uygulamada yaşadığı sorunların akademik literatüre girmesine katkı sağlayan İstanbul Esenyurt İlçesindeki kıymetli okul yöneticilerine teşekkürü bir borç bilirim. Yine çalışmanın yayın sürecinde incelemeleri ile bana yol gösteren sayın hakemlerimize ve büyük özverileriyle yayınların

${ }^{31}$ Saffet Karayaman, "School Administrators who Serve in Different Institutions Ethical Dilemmas and Their Attitudes towards These Dilemmas", Asian Journal of Education and Training, 4/3 (2018), s.208. 
ortaya çıkıp somutlaşmasında önemli katkıları olan Editörlere ve Yayın Kuruluna şükranlarımı sunarım.

\section{Kaynakça}

Ajanskamu.net. "Liyakat Şartlarını Taşımayan Müdür Atamaları Sayıştay Raporunda". 6.10.2020. https://www.ajanskamu.net/meb/liyakat-sartlarinitasimayan-mudur-atamalari-sayistay-raporunda-h111139.html.

Akan, Durdağı, İsa Yıldırım ve Sinan Yalçın. "Okul Yöneticilerine Aşağıdan Yukarı Doğru Uygulanan Yıldırma (Mobbing) Davranışları”. International Online Journal of Educational Sciences (IOJES). 5/3 (2013): 646-459.

Aydın, İnayet. Eğitim ve Öğretimde Etik. Ankara: Pegem Akademi, 2016.

Balkış Baymur, Feriha. Genel Psikoloji. İstanbul: İnkılâp Kitabevi, 2014.

Baş, Gökhan. "21. Yüzyılda Eğitim Yöneticisinin Rolündeki Değişim ve Dönüşüm”. Eğitişim Dergisi. 30 (2011).

Büte, Mustafa. "Etik İklim, Örgütsel Güven ve Bireysel Performans Arasındaki İlişki”. Atatürk Üniversitesi İktisadi ve İdari Bilimler Dergisi. 25 (2011): 171192.

Eryılmaz, Bilal. "Etik Kültürü Geliştirmek”, Türk İdare Dergisi, 459 (2008), s.1-12.

Güneş, Hasan. "Baskı Grupları ve Okullar”. 7 Şubat, 2018. https://www.kamubiz.com/baski-gruplari-ve-okullar-makale,428.html.

Gül, Hüseyin. “Çevresel Baskı Gruplarının Okulun Genel İşleyişine Etkileri (Kocaeli-İzmit Örneği)”. Kocaeli Üniversitesi Sosyal Bilimler Enstitüsü Dergisi. 11/1 (2006): 71-84.

Karayaman, Saffet. "Okul Yöneticilerinde Duygusal Zekâ ve Etik Karar Verme İlişkisi”. Turkish Studies - Education. 15/4 (2020): 2741-2756.

Karayaman, Saffet. "Yönetimde Duygusal Zekâ, İşyeri Mutluluğu ve Etik Karar İlişkisi: Okul Yöneticileri Üzerinde Bir Araştırma”. Doktora Tezi, Gelişim Üniversitesi, 2019.

Karayaman, Saffet. "School Administrators who Serve in Different Institutions Ethical Dilemmas and Their Attitudes towards These Dilemmas". Asian Journal of Education and Training. 4/3 (2018): 201-209.

Koçel, Tamer. İşletme Yöneticiliği. İstanbul: Beta Basım, 2013.

Öncü Yöneticiler. “Okul Yönetiminde Etik / Prof Bilal Eryılmaz”. 27 Aralık, 2017. http://www.oncuyoneticiler.com/yonetici-sohbetleri/okul-yonetiminde-etikprof-dr-bilal-eryilmaz/2017.

Özcan, Kenan. "Çevresel Baskı Gruplarının Okul Yönetimine Etkileri (Adıyaman İli Örneği)”. E-International Journal of EducationalResearch. 5/1 (2014): 88113.

Resmi Gazete. "Millî Eğitim Bakanlığı Eğitim Kurumlarına Yönetici Görevlendirme Yönetmeliği”. Sayı: 30455. 21 Haziran 2018. https://www.resmigaze te.gov.tr/eskiler/2018/06/20180621-8.htm.

Saban, Ahmet. Metaphors about School. Educational Administration: Theory and Practice. 14/3 (2008): 459-496.

Taymaz, Haydar. Okul Yönetimi. Ankara: Pegem Yayıncılık, 7. bs., 2003. 
Toprakçı, Erdoğan. "Güç Merkezleri Açısından Okulun Örgütsel Farklılıkları". Kuram ve Uygulamada Eğitim Yönetimi. 26 (2001): 277-287.

Tosun, Zümrüt H. ve İlke Oruç. "İnsan Kaynakları Yönetiminde Etik Dışı Davranışlar ve Yönetimi: Bir İşletmenin Personel Yönetmeliği İçerik Analizi”. İş Ahlakı Dergisi. 5/10 (2012): 149-181.

Turan, Selahattin ve Gamze Yalçın. "Okul Yöneticilerinin Yaptığı ve Yapmak İstediği İşler ile İş Doyumları Arasındaki İlişkinin İncelenmesi”. Kalem Eğitim ve Insan Bilimleri Dergisi. 5/2 /2015):11-34.

Urun, Zekeriya ve Asiye Toker Gökçe. "Okul Müdürlerinin Baskı Gruplarının İstekleri ile Başa Çıkma Taktikleri”. Journal of Teacher Education and Educators. 4/1 (2015): 102-125.

Sevgi Yücel ve İlhan Kakırman, Haz. “2016/2017 İstatistik Verileri”. İstanbul İl Milli Eğitim Müdürlüğü. 2017. https://istanbul.meb.gov.tr/meb_iys_ dosyalar/2017_04/12163411_2016-2017_Ystatistik_KitabY_Taslak.pdf （erişim 12.03.2019).

Yıldırım, Ali ve Hasan Şimşek. Sosyal Bilimlerde Nitel Araştırma Yöntemleri. Ankara: Seçkin Yayıncılık, 2006. 


\title{
Investigation of the Sources of Pressure and Power that Put School Administrators in Ethical Dilemma according to School Levels
}

\author{
SAFFET KARAYAMAN
}

\begin{abstract}
In this study, it was aimed to determine the power sources, pressure groups that push school administrators to ethical dilemma according to school categories. School principals and vice principals are considered as school principals. As school levels, it was handled in Primary, Middle and High School categories. The research is a qualitative case study and multiple case patterns are used. Fifty school administrators, who were selected with the easy accessible sampling method, participated in the study. Particular attention was paid to not identifying the participants' identities. The data were collected with standardized open-ended questions and analyzed by categorical content analysis. In the light of the data collected, the sources that caused the ethical dilemmas faced by school administrators were gathered in seven groups. As the three most intense source of ethical dilemmas in all institutions; Unions, associations and foundations' expectations; populist practices of senior authorities; skills and skills of superiors are listed. It was found that the power sources that cause ethical dilemmas faced by school administrators differ according to school types and the reasons for differentiation are discussed. In the last part, inferences are made about how school administrators can avoid ethical violations.
\end{abstract}

Keywords: School administrators, Ethical dilemma resources, Pressure, School levels 